\title{
Granuloma Annulare-like Wells Syndrome in a Child - A Case Report
}

Branislav LEKIĆ ${ }^{1}$, Mirjana GAJIĆ-VELJIĆ́, ${ }^{1,2}$, Miloš NIKOLIĆ 1,2

${ }^{1}$ Clinic of Dermatovenereology, Clinical Center of Serbia, Belgrade, Republic of Serbia

${ }^{2}$ University of Belgrade, School of Medicine, Belgrade, Republic of Serbia

*Correspondence: Miloš Nikolić, e-mail: milos.nikolic@med.bg.ac.rs

DE GRUYTER

UDC 616.5-002-053.2-07/-08

OPEN

\begin{abstract}
Wells syndrome (WS) is a rare inflammatory skin disease of unknown etiology. Possible triggers for WS include insect bites/stings, infections, medications, malignancies, and vaccination. Most cases have been reported in adults, but WS may also occur in children.

We report a case of idiopathic WS in a 12-year-old boy, who presented with pruritic papulonodular and granuloma annulare-like lesions on his legs. The patient had an excellent response to topical and systemic corticosteroids.

WS may present as plaque, granuloma annulare-like, urticaria-like, papulovesicular, bullous, papulonodular, or fixed drug eruption-like lesions. Erythematous annular lesions are most common in adults, while plaques are mostly found in children. The histopathologic features are dynamic, starting with dermal edema and infiltration of eosinophils, then flame figures develop, and finishing with the appearance of histiocytes and giant cells.

Our patient represents a rare pediatric case with granuloma annulare-like WS syndrome.
\end{abstract}

\section{Key words}

Skin Diseases; Cellulitis; Granuloma Annulare; Signs and Symptoms; Child; Eosinophilia; Diagnosis; Treatment Outcome

W ells syndrome (WS) is a rare inflammatory dermatosis, of unknown etiopathogenesis, first described by George Wells as a "recurrent granulomatous dermatitis with eosinophilia" in 1972. (1). In 1979, Wells and Smith reported eight additional cases and renamed the disease into "eosinophilic cellulitis" (2). Classically, patients present with pruritic cellulitis-like eruptions, and occasionally with papular and nodular lesions (3). The histologic findings include marked eosinophil infiltration and degranulation leading to the formation of flame figures. The flame figures are distinctive, but not pathognomonic for WS (4). The etiology is unknown, but some hypothesize that this syndrome may represent a hypersensitivity reaction to a circulating antigen. Other possible precipitating factors include infections, arthropod bites, hematological disorders, malignancies, drug reactions and recent immunization (5). Most cases have been reported in adults, but it may occur in children as well.

\section{Case report}

We present a 12-year-old Caucasian boy, with a 6-month history of erythematous pruritic papules on the legs. He was unsuccessfully treated with oral antihistamines, systemic and topical antibiotics. $\mathrm{He}$ did not have any systemic disease or known triggering factors, including insect bites, bacterial, viral, parasitic or fungal infections. Drugs were excluded as the possible cause of the condition. His personal and family history of atopic diseases was negative.

On admission, the boy presented with infiltrated papulonodular lesions and plaques, many of them of annular shape (resembling granuloma 


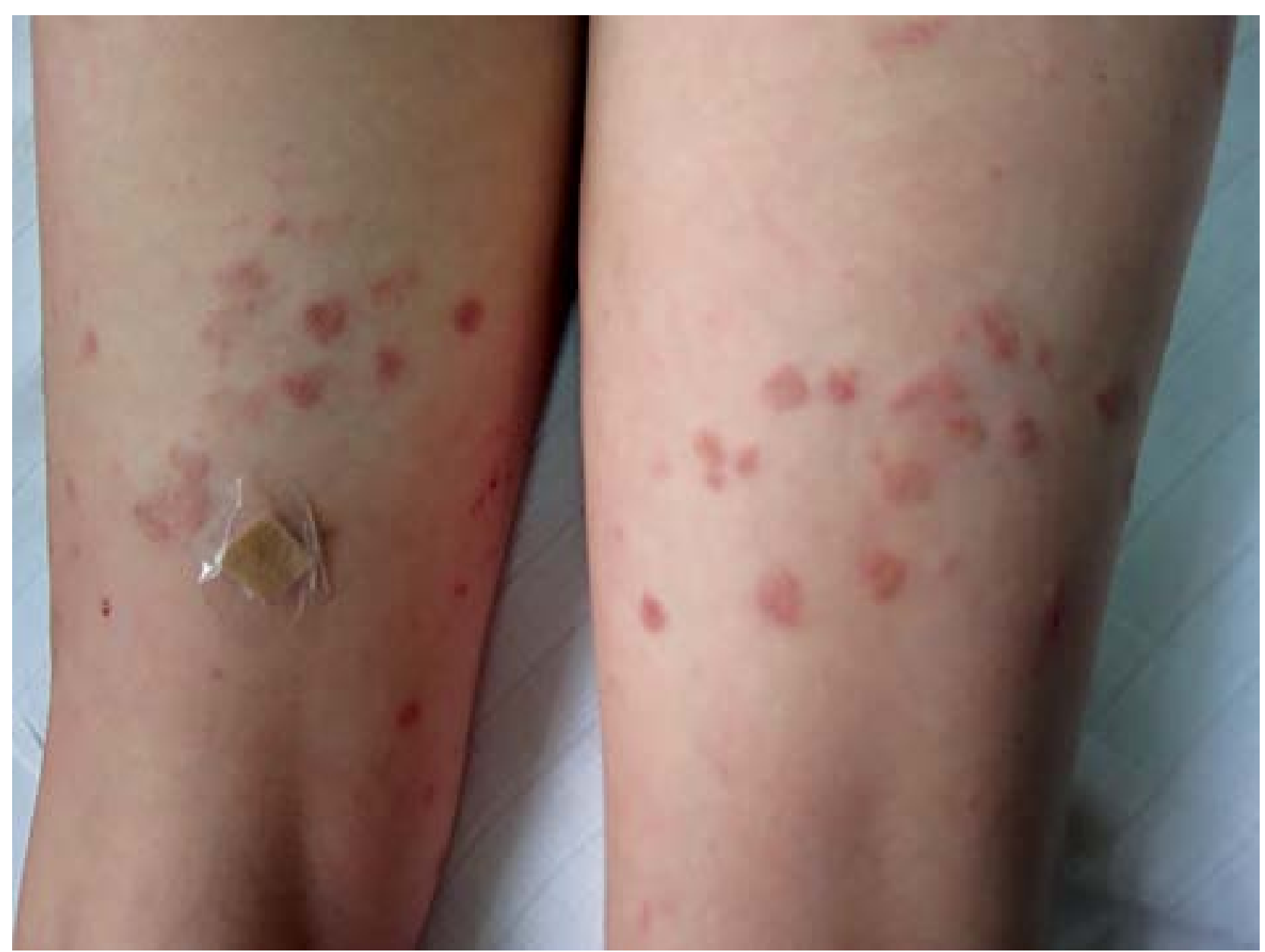

Figure 1. Papulonodular and granuloma annulare-like lesions on the thighs

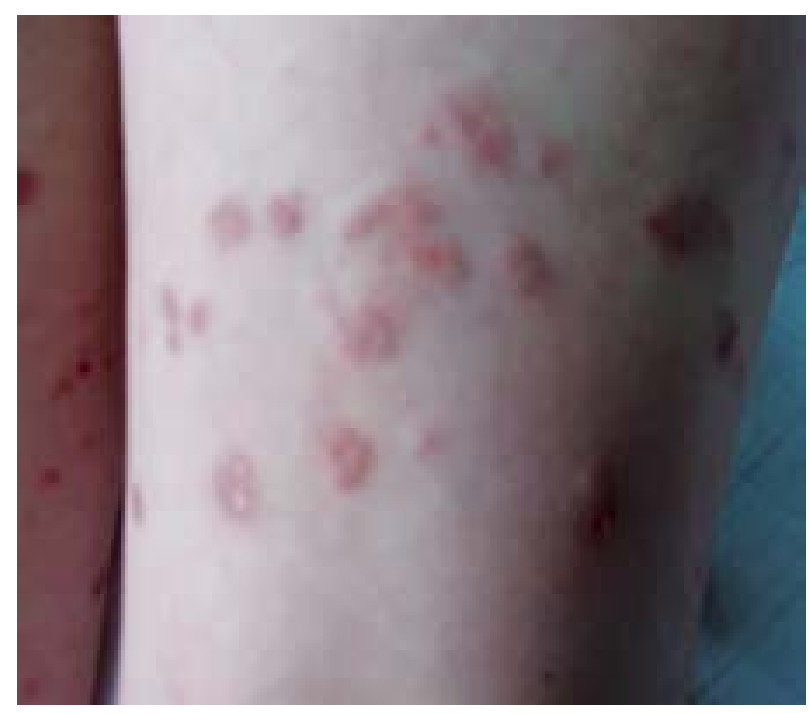

Figure 2. Granuloma annulare-like lesions on the flexor surface of the right thigh annulare), localized mainly on the flexor surface of his thighs (Figures 1 and 2 ). The lymph nodes were not enlarged. The eosinophil count was $0.73 \times 10^{9} / \mathrm{L}$ (normal $0-0.4 \times 10^{9} / \mathrm{L}$ ). Other laboratory test results (erythrocyte sedimentation rate - ESR, hepatic and renal functions tests, C-reactive protein, anti-streptolysin $\mathrm{O}$, IgE, antinuclear antibodies, urinalysis, and parasitological stool examination) were normal or negative. Ultrasonography of the abdomen and the neck soft tissues, as well as the chest X-ray-were normal.

The histopathology of a papulonodular lesions showed an interstitial infiltrate of eosinophils in the superficial dermis (Figure 3) and flame figures, consisting of amorphous eosinophilic deposits of collagen surrounded by a palisade of histiocytes and giant cells in the deep dermis (Figure 4). 


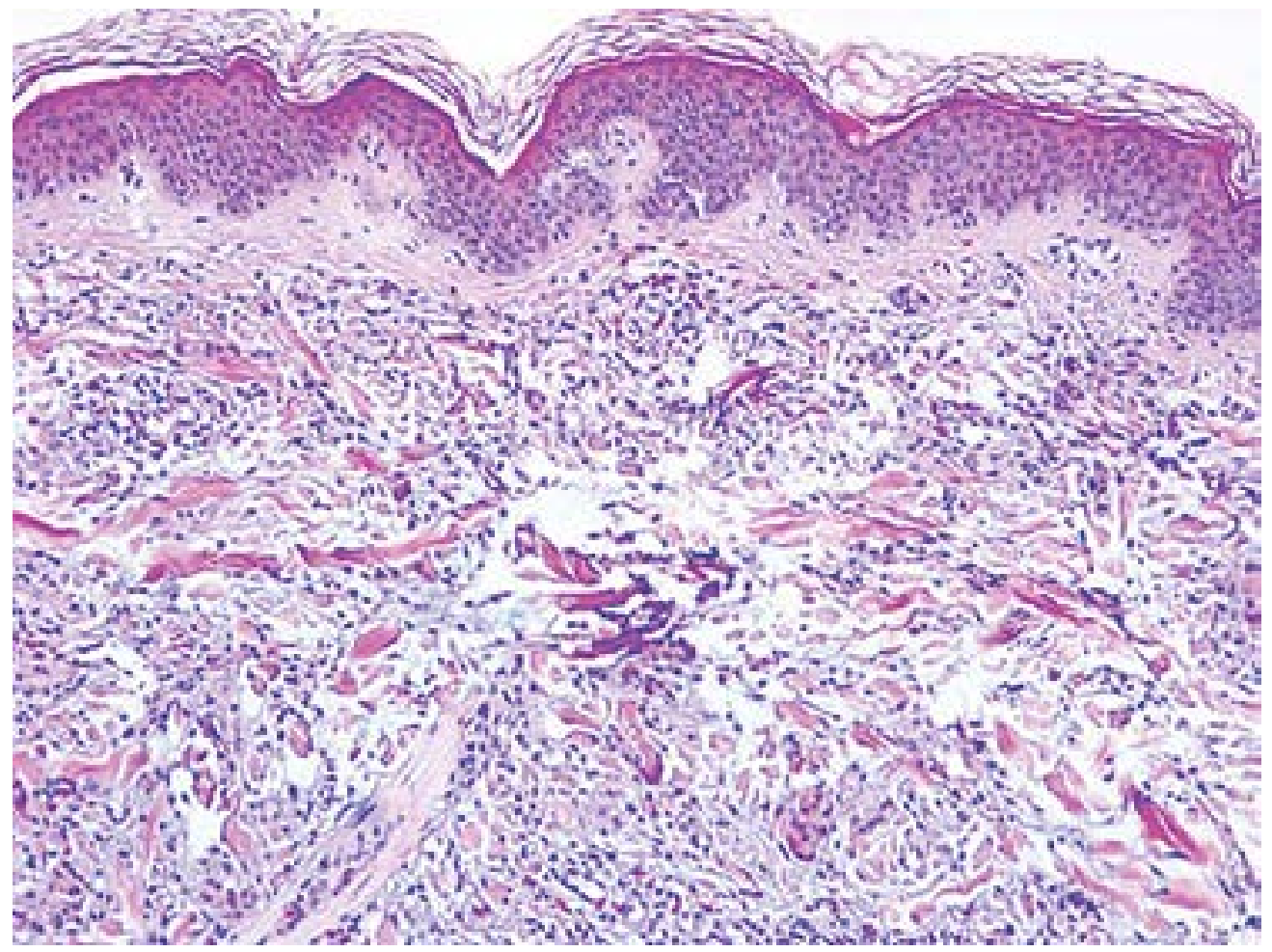

Figure 3. Superficial and deep perivascular and interstitial inflammation composed of eosinophils and lymphocytes, with flame figures throughout the dermis (HE x100).

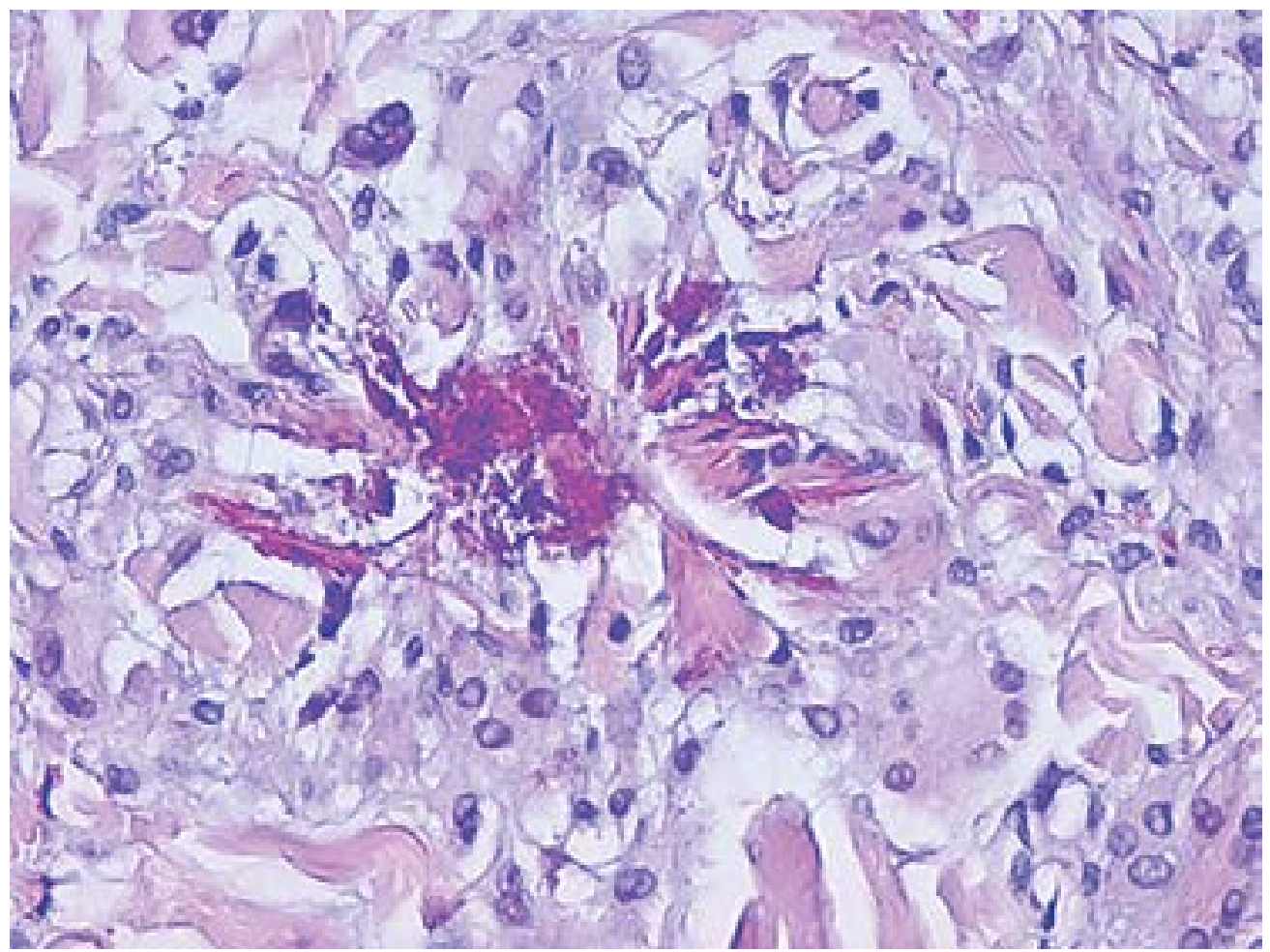

Figure 4. The regression phase of WS: flame figure, numerous histiocytes and multinucleated giant cells (HE $\mathrm{x} 400)$ 
The patient was treated with oral prednisone at $0.5 \mathrm{mg} / \mathrm{kg} /$ day with gradual dose tapering over 3 months, in combination with topical corticosteroids for three weeks and then with topical tacrolimus ointment. The therapy resulted in a complete resolution of skin lesions. The peripheral eosinophilia disappeared. There were no signs of recurrence nine months after therapy cessation.

\section{Discussion}

The pathogenesis of WS is still unknown. The first hypothesis, proposed by Wells, was that the lesions begin as an urticarial type of reaction that persists when there is an abnormal reaction to eosinophils (1). The second hypothesis was that allergic hypersensitivity may be involved in the pathogenesis: frequently associated urticaria, peripheral eosinophilia, and presence of drug/ insect/parasitic triggers pointed to a possible allergic phenomenon (6). Reported precipitanting factors comprise arthropod bites/stings (bees, spiders) (7), cutaneous viral infections (mumps, molluscum contagiosum (8), varicella (9), herpes simplex virus (10)), bacterial, parasitic, and fungal infections (5). Numerous medications have been implicated as WS triggers (antibiotics, anticholinergic agents, anesthetics, non-steroidal anti-inflammatory agents, thiazide diuretics, anti=thyroid drugs, chemotherapeutic agents, thimerosal-containing vaccines and anti-TNF agents) $(11,12,13)$. Among adults, several cases of WS have been associated with hematologic disorders, lymphoproliferative malignancies, and carcinomas (5). One case of WS was reported in a 17-year-old girl with nasopharyngeal carcinoma, and this is the only pediatric case of WS associated with malignancy (14). No precipitating factor was found in approximately half of the reported pediatric cases $(5,8)$.

Wells syndrome is diagnosed by a combination of clinical and histopathological findings (15). WS usually affects adults, but it occurs in children as well. There is no racial or gender predilection (16). Two cases of congenital WS have been described (4). The disease is often sporadic, but some familial cases have been reported (17). WS typically presents as a mildly pruritic or tender cellulitis-like eruption (5). Skin lesions may be single or multiple. WS presenting as a solitary lesion is more common in children than in adults (11). Various forms of WS have been described in the literature: plaque(s), granuloma annulare-like lesions, urticaria-like, papulovesicular, bullous, papulonodular, and fixed-drug eruption-like lesions $(11,18)$. In a case series of Caputo at al. (18), the classic plaque-type variant proved to be the most common clinical presentation in children but not in adults. In adults, erythematous annular lesions resembling granuloma annulare were most frequently found.

Blood eosinophilia was reported in approximately $50 \%$ of cases during the active phase of the disease. ESR was elevated in some patients. Increased $\mathrm{IgE}$ was described in several reports (5, 11). Systemic symptoms, such as asthma, arthralgia, fever and lymphadenopathy have been described, and these findings may be indicators of a more severe or progressive course (5).

The histopathological features are dynamic: 1 ) the acute phase exhibits dermal edema and diffuse dermal infiltration of eosinophils, without signs of vasculitis; 2) the subacute phase is characterized by infiltrate of phagocytic histiocytes together with flame figures where amorphous or granular eosinophilic material adheres to collagen and 3) the regression phase shows gradual disappearance of eosinophils with persistence of histiocytes and appearance of giant cells around collagen deposits, forming microgranulomas $(4,11,18)$. Flame figures are characteristic but not pathognomonic for WS. These figures represent a histological cutaneous reaction pattern and may be detected in other inflammatory dermatoses associated with cutaneous eosinophilia such as bullous pemphigoid, herpes gestationis, eczema, prurigo, arthropod bites/stings, scabies and drug eruptions $(15,19)$. Approximately $50 \%$ of patients with WS showed evidence of flame figures (18). In most cases direct immunofluorescence was negative (4).

The differential diagnosis of WS includes bacterial cellulitis, erythema chronicum migrans, erythema annulare centrifugum, arthropod bites/ 
Table 1. Proposed diagnostic criteria for WS *

\section{Major ( 2 of 4 required)}

1. Diverse clinical picture to include any

of the previously reported variants:

- Plaque type

- Granuloma annulare-like

- Urticaria-like

- Papulovesicular

- Bullous

- Papulonodular

- Fixed-drug eruption-like

\section{Minor (at least 1 required)}

1. Flame figures
2. Relapsing, remitting course

3. No evidence of systemic disease
2. Histology: Granulomatous changes

3. Peripheral eosinophilia not persistent and not greater than $>1500 / \mu \mathrm{L}$

4. Histology: eosinophilic infiltrate, no vasculitis

4. Triggering factor (eg. drug)

${ }^{*}$ Heelan K et al. J Dermatol Case Rep 2013;7:113-20. ${ }^{11}$

stings, chronic idiopathic urticaria, urticarial vasculitis, Churg-Strauss syndrome, hypereosinophilic syndrome and eosinophilic fasciitis (5, 11, 19).

Heelan et al. (11) proposed diagnostic criteria for WS: four major (two of which need to be present) and four minor criteria (at least one of which needs to be present) (Table 1).

\section{Conclusion}

Many WS cases resolve spontaneously, and treatment for WS is sometimes unnecessary. The standard first-line treatment includes systemic corticosteroids, both for adults and children, and most cases seem to respond to oral prednisone. Treatment with topical corticosteroids has been reported, both as monotherapy, and in combination 
with systemic corticosteroid therapy (5, 20). Successful treatment outcomes were reported with cyclosporine A, minocycline, colchicine, antimalarials, azathioprine, interferon- $\alpha$, antihistamines, psoralen with ultraviolet A $(19,20)$.

In our patient, no precipitating factor was found, and eruptions cleared with systemic and topical corticosteroid therapy. The regressing papules and macules were additionally treated with topical tacrolimus ointment. Our patient's presentation with papulonodular and granuloma annulare-like lesions is a rare clinical variant of WS in children.

\section{References:}

1. Wells GC. Recurrent granulomatous dermatitis with eosinophilia. Trans St Johns Hosp Dermatol Soc. 1971;57(1):46-56.

2. Wells GC, Smith NP. Eosinophilic cellulitis. Br J Dermatol. 1979;100(1):101-9.

3. España A, Sanz ML, Sola J, Gil P. Wells' syndrome (eosinophilic cellulitis): correlation between clinical activity, eosinophil levels, eosinophil cation protein and interleukin-5. Br J Dermatol. 1999;140(1):127-30.

4. Moossavi M, Mehregan DR. Wells' syndrome: a clinical and histopathologic review of seven cases. Int J Dermatol. 2003;42(1):62-7.

5. Gilliam AE, Bruckner AL, Howard RM, Lee BP, Wu S, Frieden IJ. Bullous "cellulitis" with eosinophilia: case report and review of Wells' syndrome in childhood. Pediatrics. 2005;116(1):e149-55.

6. Mitchell AJ, Anderson TF, Headington JT, Rasmussen JE. Recurrent granulomatous dermatitis with eosinophilia. Int J Dermatol. 1984;23(3):198-202.

7. Clark DP, Anderson PC. Eosinophilic cellulitis caused by arthropod bites. Int J Dermatol. 1988;27(6):411-2.

8. Stavropoulos PG, Kostakis PG, Panagiotopoulos AK,
Papakonstantinou AM, Petridis AP, Georgala S. Molluscum contagiosum and cryosurgery: triggering factors for Wells' syndrome? Acta Derm Venereol. 2003;83(5):380-1.

9. Reichel M, Isseroff RR, Vogt PJ, Gendour-Edwards R. Wells' syndrome in children: varicella infection as a precipitating event. Br J Dermatol. 1991;124(2):187-90.

10.Ludwig RJ, Grundmann-Kollmann M, Holtmeier W, Wolter M, Glas J, Podda M, et al. Herpes simplex virus type 2-associated eosinophilic cellulitis (Wells' syndrome). J Am Acad Dermatol. 2003;48(5 suppl):S60-1.

11.Heelan K, Ryan JF, Shear NH, Egan CA. Wells' syndrome (eosinophilic cellulitis): Proposed diagnostic criteria and a literature review of the drug-induced variant. J Dermatol Case Rep. 2013;7(4):113-20.

12.Koh KJ, Warren L, Moore L, James C, Thompson GN. Wells' syndrome following thiomersal-containing vaccinations. Australas J Dermatol. 2003;44(3):199-202.

13. Moreno M, Luelmo J, Monteagudo M, Bella R, Casanovas A. Wells' syndrome related to tetanus vaccine. Int J Dermatol. 1997;36(7):524-5.

14.Zachary CB, Wong E, Wilson-Jones E. Eosinophilic cellulitis. Ann Dermatol Venereol. 1984;111(8):777-8.

15.Aberer W, Konrad K, Wolff K. Wells' syndrome is a distinctive disease entity and not a histologic diagnosis. J Am Acad Dermatol. 1988;18(1 Pt 1):105-14.

16.Anderson CR, Jenkins D, Tron V, Prendiville JS. Wells' syndrome in childhood: case report and review of the literature. J Am Acad Dermatol. 1995;33(5 Pt 2):857-64.

17.Davis MD, Brown AC, Blackston RD, Gaughf C, Peterson EA, Gleich GJ, et al. Familial eosinophilic cellulitis, dysmorphic habitus, and mental retardation. J Am Acad Dermatol. 1998;38(6 Pt 1):919-28.

18. Caputo R, Marzano AV, Vezzoli P, Lunardon L. Wells syndrome in adults and children: a report of 19 cases. Arch Dermatol. 2006;142(9):1157-61.

19.Karabudak O, Dogan B, Taskapan O, Harmanyeri Y. Eosinophilic cellulitis presented with semicircular pattern. J Dermatol. 2006;33(11):798-801.

20.Räßler F, Lukács J, Elsner P. Treatment of eosinophilic cellulitis (Wells syndrome) - a systematic review. J Eur Acad Dermatol Venereol. 2016;30(9):1465-79.

\section{Wells-ov sindrom nalik na granuloma annulare kod deteta - prikaz slučaja}

\section{Sažetak}

Velsov (Wells) sindrom je retka inflamatorna dermatoza nepoznate etiologije. Trigeri mogu biti ujedi/ubodi artropoda, infekcije, lekovi, maligniteti i vakcinacija. U većini slučajeva se dijagnostikuje kod odraslih, ali se može javiti i kod dece.
Prikazujemo slučaj idiopatskog Velsovog sindroma kod dvanaestogodišnjeg dečaka, sa pruriginoznim papulonodularnim i lezijama nalik na granuloma annulare lokalizovanim na nogama. Promene su se brzo povlačile na lokalnu i sistemsku kortikosteroidnu 
terapiju, bez znakova recidiva.

U literaturi su opisane različite forme Velsovog sindroma $\mathrm{u}$ vidu plaka, nalik na granuloma annulare, urtikarijalne, papulovezukularne, bulozne, papulonodularne i lezije nalik na erythema fixum. Kod odraslih, najčešća klinička prezentacija su eritematozne anularne lezije, a kod dece plak-lezije. Histopatološke karakteristike su dinamične, počinju kao edem i infiltracija derma eozinofilima, potom dolazi do stvaranja "plamenih figura“ i završavaju se pojavom histiocita i multinuklearnih džinovskih ćelija.

Kod našeg pacijenta Velsov sindrom se prezentovao u vidu lezija nalik na granuloma annulare koja se retko dijagnostikuje u dečjem uzrastu.

\section{Ključne reči}

Kožne bolesti; Celulitis; Granuloma Annulare; Znaci i simptomi; Dete; Eozinofilija; Dijagnoza; Ishod terapije 